ACTA MYCOLOGICA

Vol. 45 (2): 239-246

2010
Dedicated to Professor Barbara Gumińska on the occasion of her eighty-fifth birthday

\title{
Some observations of slime moulds on wood and litter in beech forests
}

\author{
DOMINIKA ŚLUSARCZYK \\ Department of Mycology, University of Łódź \\ Banacha 12/16, PL-90-237 Łódź, dominika@biol.uni.lodz.pl
}

Ślusarczyk D.: Some observations of slime moulds on wood and litter in beech forests. Acta Mycol. 45 (2): 239-246, 2010.

The results of research into slime moulds in beech forest reserves in Central Poland are presented. Thirty species of slime moulds directly associated with beech wood and beech litter were recorded. Species associated with different decay phases of beech wood and litter were identified.

Key words: Mycetozoa, ecology, beech forests, nature reserves

\section{INTRODUCTION}

Myxomycete species from Central Poland have so far been listed in two studies published by Orzechowski (1966) and Kalinowska-Kucharska (1975). Orzechowski gives 44 species from forest areas within the Łódź town boundaries and some parks in Łódź. Kalinowska-Kucharska provides a list of slime moulds collected by Lawrynowicz in nature reserves in the Łódź voivodeship, mostly in the Tilio-Carpinetum Tracz. 1962 and Potentillo albae-Quercetum Libb. 1933 associations (Lawrynowicz 1973).

Present studies were conducted in nature reserves in Central Poalnd over four years. Slime moulds occurring on fallen beech logs, trunks and stumps and beech litter were especially interesting. Of them, six taxa are new to the area: Fuligo leviderma, Hemitrichia clavata, Collaria arcyrionema (Lamproderma arcyrionema), Physarum leucophaeum, P. notabile, Stemonitis pallida (Seta, Drozdowicz 2004).

The aim of this study is to identify species of slime moulds associated with beech wood and beech litter during their development. 


\section{STUDY AREA}

The study area belongs to the Wzniesienia Lódzkie hills mesoregion according to Kondracki (1998). Investigations were conducted in three nature reserves and a natural site in Central Poland where European beech reaches the northern limit of its natural range (Fig. 1).

The Wiączyń reserve was established in a 1300 ha forest complex (Las Wiączyński forest) and covers an area of 8.40 ha. It comprises sections 170a, 170c and 176a, and is part of the former Puszcza Łódzka old-growth forest. The reserve protects a natural deciduous forest on the northern range limit of beech and fir, and comprises a shade forest. The field layer is composed of few species with a very small cover. This community type is the most representative of mixed beech forests and resembles acidic lowland beech forests (Olaczek 1962; personal inf. 2004).

The Gałków reserve covers an area of 57.85 ha and comprises forest sections 240, 241 and 244a, b, c, d. It is one of the oldest reserves in the Lódź voivodeship. It protects Fagus sylvatica and Abies alba which grow here at the limit of their geographic range. As reported by Sowa and Olaczek (1971), the primeval beechfir forest has been preserved in the reserve. However, it differs considerably from similar forests in southern Poland which are distinguished by floral poverty, the absence of species associated with beech and the mountainous character. The field layer is formed by plants typical of beech forests, oak-hornbeam forests and other deciduous forests. Approximately 29 beeches of natural and historic importance grow in the reserve. They are over 150 years old, with some as old as 300 years.

The Parowy Janinowskie reserve is situated in the northern part of the Janinów natural site complex, one of the largest sites of the natural occurrence of common beech (557 ha) in Central Poland (Rutowicz, Sowa 1976) and one of the areas of greatest value in the Wzniesienia Lódzkie Landscape Park (Kurowski 1986, 1994, 1998). It comprises sections 37b, c, 38, 39a, b, f, 43b, 44a, b, and is part of a gentle $\mathrm{N}$-facing slope covered with a network of original erosion ravines. Luzulo pilosae-Fagetum phytoceonoses cover considerable areas of the reserve (Kurowski 1994).

The Paprotnia natural site covers 63.88 ha, comprises sections $221-224$ and is situated on the line of the highest hills running from Zgierz to the vicinity of Brzeziny. Circaeo-Alnetum, Tilio-Carpinetum and Luzulo pilosae-Fagetum forest associations were identified within the site. They cover the entire hilly area of the moraine plateau and its edge. A dense and healthy 90 -year-old beech tree stand prevails. The edge, steep slopes and local elevations are covered by its poor variant; flat areas are covered by a variant with Anemone nemorosa (Łuczak, Łuczak 2000a, b).

The four areas are interesting sites of Fagus sylvatica and have been studied by botanists, mycologists, mycosociologists and phytopathologists. Herbarium collections of fungi gathered over a period of 50 years are deposited in the Herbarium Universitatis Lodziensis (LOD F). Herbarium materials were analysed to identify life conditions of beech at the limit of its natural range. Results will be published in successive papers. This study discusses myxomycetes and is the first in the series. 


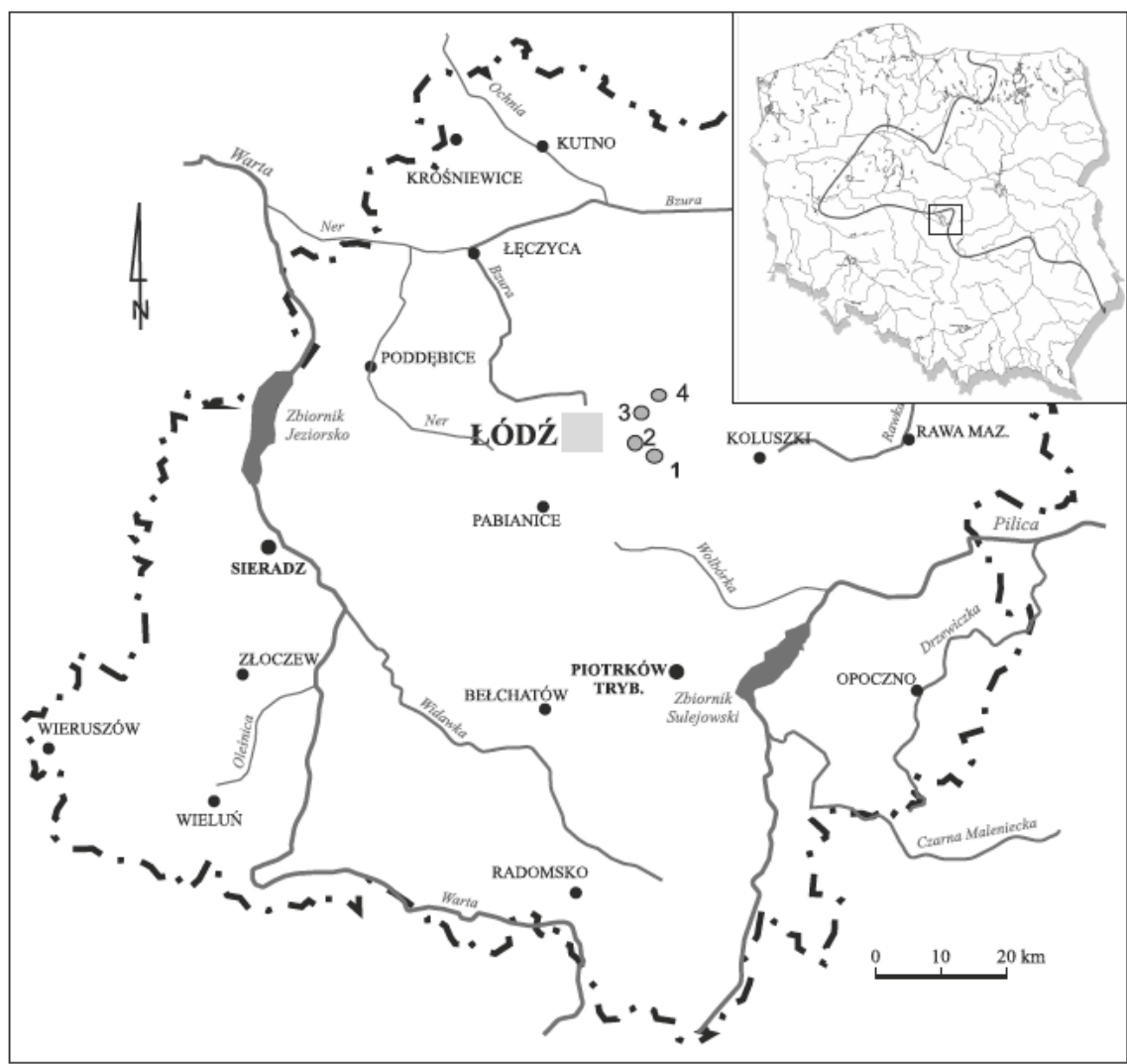

Fig. 1. Study area: 1 - the Galków reserve; 2 - the Wiączyń reserve; 3 - Paprotnia natural site; 4 - the Parowy Janinowskie reserve.

\section{MATERIAL AND METHODS}

Field studies were conducted in 2000-2004. Observations were carried out on the abundant substrate lying on the forest floor (beech wood: trunks, stumps, logs, beech litter). A three-stage wood decay scale (Kreisel 1961; Runge 1978, 1979; Lisiewska 1992) was used in the study:

1) the initial phase that begins in month 7 to 10 and lasts up to two years after a tree is felled;

2) the optimal phase that occurs after two vegetative seasons and lasts 2-5 years;

3 ) the end (terminal) phase. It is the longest phase and lasts 5-15 years.

Morphological and anatomical characters were examined in the material. Specimens were observed with a NIKON SMZ-10A binocular and a NIKON Eclipse E-200 light microscope. Monographs by Krzemieniewska (1960) and Neubert, Nowotny, Bauman \& Marx (1993, 1995, 2000) were used to identify the taxa. The nomenclature was accepted after Drozdowicz et al. (2003), updated according to Lado (2005-2010). 
Current names of slime moulds were also used in the citations from source studies. The name under which a species was published by the original author is given in brackets.

The specimens collected are deposited in the Herbarium Universitatis Lodziensis (LOD F).

\section{RESULTS}

\section{LIST OF SPECIES}

Arcyria cinerea (Bull.) Pers. - Wiączyń reserve: on fallen branches of Fagus, VII 2002; Parowy Janinowskie reserve: on decaying beech wood, VII 2004.

A. denudata (L.) Wettst. -Wiączyń reserve: on beech logs, IX 2000, V, XI 2001, V 2002, III 2002, III 2003; Gałków reserve: on beech logs, X 2000, VII 2003; Paprotnia natural site: on beech logs, X 2002.

A. obvelata (Oeder) Onsberg - Wiączyń reserve: on Fagus wood; IV 2001, V, XI 2002, VIII, X 2003; Gałków reserve: on Fagus wood, IX 2003; Paprotnia natural site: on Fagus wood, VII 2001.

Badhamia utricularis (Bull.) Berk. - Wiączyń reserve: on decaying beech wood, X 2000.

Ceratiomyxa fruticulosa (O. F. Müll.) T. Macbr. - Wiączyń reserve: on logs of Fagus; IX 2000; Gałków reserve: on logs of Fagus, VII 2001, VII 2003; Parowy Janinowskie reserve: VII 2001; Paprotnia natural site: VII 2001.

Collaria arcyrionema (Rostaf.) Nann.-Bremek. ex Lado - Parowy Janinowskie reserve: on a Fagus stump, VII 2001.

Comatricha nigra (Pers. ex J. F. Gmel) J. Schröt. - Wiączyń reserve: on fallen branches of Fagus, X 2003.

Diachea leucopodia (Bull.) Rostaf. - Wiączyń reserve: on fallen beech leaves, VIII-IX 2003.

Didymium melanospermum (Pers.) T. Macbr. - Gałków reserve: on fallen beech leaves; VIII 2003.

Fuligo leviderma H. Neubert, Nowotny \& K. Baumann - Gałków reserve: on fallen beech leaves and fruits; VIII 2001.

F. septica (L.) F. H. Wigg. - Wiączyń reserve: on fallen beech leaves, IX 2000, VIII 2001, IX 2003; Gałków reserve: on fallen beech leaves, II VII 2001, VII 2003; Paprotnia natural site: on fallen beech leaves, VI-VII 2000, VI-VII 2001, VI 2002; Parowy Janinowskie reserve: on fallen beech leaves, VIII 2001, VI 2002.

Hemitrichia clavata (Pers.) Rostaf. - Wiączyń reserve: on a log of Fagus; X 2000.

Lamproderma columbinum (Pers.) Rostaf. - Paprotnia natural site: on decaying Fagus wood, VII 2001.

Leocarpus fragilis (Dicks.) Rostaf. - Wiączyń reserve: on pieces of Fagus bark, VIII 2001.

Lycogala epidendrum (L.) Fr. - Wiączyń reserve: on Fagus trunks, VI, IX 2000, VII 2001; Gałków reserve: on Fagus trunks, X 2000, VII 2001, IX 2003; Paprotnia natural site: on Fagus trunks, VIII 2000, VII, X 2001; Parowy Janinowskie reserve: on Fagus trunks, VIIVIII 2001, X 2003.

Metatrichia vesparia (Batsch) Nann.-Bremek. ex G. M. Martin \& Alexop. - Wiączyń reserve: on a decaying log of Fagus, V 2001, III-V 2002, XI 2002; Gałków reserve: on a decaying log of Fagus, IV 2001, IX 2003, IX 2004; Paprotnia natural site: on Fagus trunks, II 2003; Parowy Janinowskie reserve: on Fagus trunks, III, VII-VIII 2001. 
Physarum album (Bull.) Chevall. - Wiączyń reserve: on beech wood, VIII 2003, IX 2004.

P. cinereum (Batsch) Pers. - Wiączyń reserve: on beech wood, X 2000, IX 2003.

P. leucophaeum Fr. - Wiączyń reserve: on a beech log, IX 2000.

P. notabile T. Macbr. - Wiączyń reserve: on a beech log, IX 2000.

P. virescens Ditmar in Sturm - Gałków reserve: on fallen beech leaves, VIII 2001.

Reticularia lycoperdon Bull. - Wiączyń reserve: on decaying trunks of Fagus, IX 2000, IV 2002, VI 2005.

Stemonitis axifera (Bull.) T. Macbr. - Wiączyń reserve: on decaying Fagus wood, X 2000, VII 2003, VI 2005.

S. pallida Wingate - Parowy Janinowskie reserve: on decaying Fagus wood, VIII 2001.

Stemonitopsis typhina (F. H. Wigg.) Nann.-Bremek. - Wiączyń reserve: decaying wood and fallen leaves of Fagus, IX 2000, IX 2003, VI 2005; Parowy Janinowskie reserve: VII 2004.

Trichia decipiens (Pers.) T. Macbr.- Wiączyń reserve: on beech wood, X 2003.

T. favoginea (Batsch) Pers. - Wiączyń reserve: on beech wood, IV 2001.

T. scabra Rostaf. - Wiączyń reserve: on a decaying log of Fagus, III 2002, XI 2004.

T. varia (Pers. ex J. F. Gmel.) Pers. - Wiączyń reserve: on beech wood, X 2000, X 2001; Gałków reserve: on beech wood, IV 2001.

Tubulifera arachnoidea Jacq.- Wiączyń reserve: on a beech log, IX 2000, VIII 2001; Gałków reserve: on beech wood, VII 2001, VI 2002; Parowy Janinowskie reserve: VIII 2001, VII 2004.

\section{DISCUSSION}

Thirty species of slime moulds that occurred directly on beech trunks, stumps and logs and on beech litter composed of small beech twigs, bark pieces, fallen leaves and beech fruits were recorded.

An ecological analysis of the results shows that some species, e.g., Stemonitis axifera or Arcyria denudata, preferred beech wood without bark in the optimal decay phase. Other species, e.g., Lycogala epidendrum, Tubulifera arachnoidea and Hemitrichia clavata, occurred on the bark of logs in the optimal and end decay phases. Metatrichia vesparia and Trichia scabra mostly colonised logs of Fagus sylvatica in the end decay stage.

The present results correspond to those reported in similar studies. In particular, investigations conducted by Drozdowicz (1992a, b, 2008) confirm the observations that beech wood, and especially beech logs in the end decay phase, are a good substrate for the development of slime moulds. A comparison of the results collected in the Ojców National Park and Central Poland shows that 22 species occur in both areas on beech logs. Only individual taxa distinguish the mountainous area from the lowland area.

Studies conducted by Stojanowska and Panek (2004a, b) in two nature reserves near Wałbrzych (SW Poland) also confirm that slime moulds develop very well on the wood of deciduous trees. Thirty three species preferring beech wood and 31 species preferring limewood are listed. Species that mostly occur on beech stumps include Arcyria cinerea, A. denudata, A. incarnata, Ceratiomyxa fruticulosa, Comatricha pulchella, Hemitrichia clavata, H. serpula, Collaria 
arcyrionema (Lamproderma arcyrionema), Lycogala epidendrum, Metatrichia floriformis, Physarum album (P. nutans), P. leucophaeum, Stemonitis fusca, Stemonitopsis typhina, Trichia sabra and T. varia.

The occurrence of 29 species of slime moulds was recorded in studies conducted by Miśkiewicz (2001) in the Dentario glandulosae-Fagetum and Querco-Fagetum communities in the Bukowiec reserve in the Carpathian Mts. The taxa were associated with beech logs or lying stumps of Fagus sylvatica: Arcyria cinerea, A. denudata, Hemitrichia clavata, Lycogala epidendrum, Metatrichia vesparia (M. vesparium) and Stemonitis axifera. These species also occurred in the sites investigated by the present author and were recorded by Stojanowska (1979), Drozdowicz (1992b, 2008) and Ing (1994), who reports 21 species associated with the wood of Fagus sylvatica.

Stojanowska (1979) reports 42 myxomycete species on rotting beech wood from the Opole region, Góry Kaczawskie Mts, Góry Bialske Mts, Ślęża massif, Wzgórza Trzebnicko-Ostrzeszowskie hills and Karkonosze Mts. However, these taxa have a broad range of occurrence. Only seven of them colonise beech wood and do not occur on the wood of other deciduous trees. Twenty five species developed in different combinations close together, both on small trunks and on large beech logs. Stojanowska lists the following species in order of occurrence frequency: Trichia varia, Metatrichia vesparia (Hemitrichia vesparium), H. clavata, Stemonitopsis typhina (Comatricha typhoides), Trichia scabra, Trichia denudata, Stemonitis fusca, Physarum album (P. nutans), Lycogala epidendrum, Trichia persimilis, T. favoginea, Metatrichia floriformis (Trichia floriformis), Trichia botrytis, Hemitrichia serpula, Fuligo rufa, Stemonitis axifera (Stemonitis ferruginea), Badhamia utricularis, Lycogala conicum, Trichia olivacea (a taxon currently considered to be a variant of T. decipiens), Physarum leucopheum, Physarum globuliferum, Trichia decipiens, Lycogala exiguum, Arcyria affinis, Ceratiomyxa fruticulosa.

Studies conducted in the Białowieża old-growth forest (Chlebicki et al. 1996) also showed that as many as 38 species of the 44 species recorded at the CRYPTO programme research plot are associated with strongly decayed wood and mostly occur on wood previously colonised by fungi.

The composition of slime moulds recorded in the litter is also characteristic. $A r$ cyria cinerea, $A$. denudata and Comatricha nigra mostly occurred on beech twigs while Diachea leucopodia, Didymium melanospermum, Fuligo septica and Physarum virescens colonised beech leaves. Stojanowska (1983) gives a list of species associated with the litter, also beech litter, in her long-term studies on slime moulds. These include species recoded in the study area:Arcyria incarnata, Comatricha nigra (on dry leaves and fallen twigs), Diachea leucopodia, Didymium melanospermum, Leocarpus fragilis, Physarum notabile (on beech bark lying on the forest floor) and Physarum virescens.

\section{CONCLUSIONS}

Beech stumps, trunks, logs and litter are an excellent site for the development of many myxomycete species. The results confirm special preferences of slime moulds for beech wood observed by other authors. Stemonitis axifera or Arcyria denudata preferred bark-free beech wood in the optimal decay phase. Other species, e.g., 
Lycogala epidendrum, Tubulifera arachnoidea, Hemitrichia clavata, occurred on the bark of logs also in the optimal decay phase. Metatrichia vesparia and Trichia scabra most frequently colonised logs of Fagus sylvatica in the end decay phase. Diachea leucopodia, Didymium melanospermum, Fuligo septica, F. leviderma and Physarum virescens mostly occurred in the beech litter.

The investigations show that dead beech wood is a major and irreplaceable factor in forest diversity. It plays an important role in preserving particularly interesting and rare species of slime moulds that are also characteristic of wood and litter of Fagus sylvatica.

Acknowledgements. The author thanks Dr Anna Drozdowicz (Kraków) for confirming the identification of slime moulds. I am very grateful to Professor Krystyna Czyżewska (Łódź) for helpful discussion and Professor Maria Ławrynowicz (Łódź) for valuable comments on the manuscript. This work was supported by the Polish Ministry of Science and Higher Education (grant No. 2 P04G 08026).

\section{REFERENCES}

Chlebicki A., Żarnowiec J., Cieśliński S., Klama H., Bujakiewicz A., Załuski T. 1996. Epixylites, lignicolous fungi and theire links with different kinds of wood. (In:) J. B. Faliński, W. Mułenko (eds). Cryptogamous plants in the forest communities of Białowieża National Park. Phytocoenosis 8, Archivum Geobotanicum 6: 75-109.

Drozdowicz A. 1992a. Slime moulds (Myxomycetes) of the Ojców National Park. II. Ecological problems. Zeszyty Naukowe Uniwersytetu Jagiellońskiego, Prace Botaniczne 24: 147-159.

Drozdowicz A. 1992b. Slime moulds (Myxomycetes) of the Ojców National Park. III. Beech and fir logs as microhabitats of slime moulds. Zeszyty Naukowe Uniwersytetu Jagiellońskiego, Prace Botaniczne 24: $161-170$.

Drozdowicz A. 2008. Śluzowce Ojcowskiego Parku Narodowego. (In:) A. Klasa, J. Partyka (eds). Monografia Ojcowskiego Parku Narodowego. Przyroda. OPN, Ojców: 263-278.

Drozdowicz A., Ronikier A., Stojanowska W., Panek E. 2003. Myxomycetes of Poland. A checklist. Krytyczna lista śluzowców Polski. W. Szafer Institute of Botany, Polish Academy of Sciences, Kraków, $103 \mathrm{pp}$.

Ing B. 1994. The phytosociology of myxomycetes. New Phytol. 126: 175-201.

Kalinowska-Kucharska E. 1975. Materials to the flora of Myxomycetes of Central Poland. Acta Mycol. 11 (2): 93-99.

Kondracki J. 1998. Geografia regionalna Polski. PWN, Warszawa: 179-201.

Kreisel H. 1961. Die Entwicklung der Mykozönose an Fagus-Stubben auf nord-deutschen Kahlschlägen. Feddes Repertorium 139: 227-232.

Krzemieniewska H. 1960. Śluzowce Polski na tle flory śluzowców europejskich. PWN, Warszawa.

Kurowski J. K. 1986. Ocena stanu ochrony flory w rezerwatach przyrody Polski Środkowej. Acta Uni. Lodz., Folia sozol. 3: 205-224.

Kurowski J. K. 1994. Dokumentacja projektowa rezerwatu leśnego Parowy Janinowskie w woj. skierniewickim. Katedra Botaniki UŁ: 1-20 (msc.).

Kurowski J. K. (ed.) 1998. Park Krajobrazowy Wzniesień Łódzkich. Monografia. WFOŚiGW w Łodzi. Eko-Wynik, Łódź, 180 pp.

Lado C. 2005-2010. An on line nomenclatural information system of Eumycetozoa. http://www.nomen. eumycetozoa.com (20.06.2010).

Ławrynowicz M. 1973. Grzyby wyższe makroskopowe w grądach Polski środkowej. Acta Mycol. 9 (2): 133-204.

Lisiewska M. 1992. Macrofungi on special substrates. (In:) W. Winterhoff (ed.). Fungi in Vegetation Science. Kluwer Academic Publishers, the Netherlands: 151-182.

Łuczak M., Łuczak A. 2000a. Szata roślinna uroczyska Paprotnia w Parku Krajobrazowym Wzniesień Łódzkich. Acta Univ. Lodz., Folia bot. 14: 79-109.

Łuczak M., Łuczak A. 2000b. Struktura biologiczna i dynamika drzewostanu uroczyska Paprotnia w Parku Krajobrazowym Wzniesień Łódzkich. Acta Univ. Lodz., Folia bot. 14: 111-123. 
Miśkiewicz A. 2001. Slime moulds occurring in the Bukowiec reserve (W Carpathians). Acta Mycol. 36 (1): 21-29.

Neubert H., Nowotny W., Baumann K., Marx H. 1993-2000. Die Myxomyceten Deutschlands und des angrenzenden Alpenraumes unter besonderer Berücksichtigung Österreichs. 1 (1993), 2 (1995), 3 (2000). Verlag Karlheinz Baumann, Gomaringen.

Olaczek R. 1962. Rezerwat bukowy Wiączyń. Zesz. Nauk. UŁ, Seria II, Łódź 13: 93-107.

Orzechowski T. 1966. Śluzowce stwierdzone w okolicach Łodzi oraz w parkach łódzkich. Fragm. Flor. Geobot. 12 (2): 209-214.

Runge A. 1978. Pilzsukzession auf Kiefernstümpfen. Z. Mykol. 44 (2): 295-301.

Runge A. 1979. Pilz-Assoziationen auf Holz in Mitteleuropa. Z. Mykol. 46 (1): 95-102.

Rutowicz H., Sowa R. 1976. Buczyna uroczyska Janinów koło Brzezin. Zesz. Nauk. UŁ. Seria II, Łódź 14: 3-34.

Seta D., Drozdowicz A. 2004. Nowe stanowiska śluzowców (Myxomycetes) na terenie Polski Środkowej. Streszczenia IV Ogólnopolskiego Sympozjum Mikologicznego „Grzyby w środowisku naturalnym. Metody badań terenowych". Sandomierz: 35.

Sowa R., Olaczek R. 1971. Roślinność lasu jodłowo-bukowego rezerwatu Gałków pod Łodzią. Ochr. Przyr. 36: 131-169.

Stojanowska W. 1979. Obserwacje nad florą śluzowców butwiejącego drewna buka. Acta Mycol. 15 (1): $167-174$.

Stojanowska W. 1983. Myxomycetes ściółki. Acta Mycol. 19 (1): 21-30.

Stojanowska W., Panek E. 2004a. Myxomycetes of the nature reserve near Wałbrzych (SW Poland). Part I. List of taxa and quantitative analysis. Acta Mycol. 39 (1): 47-63.

Stojanowska W., Panek E. 2004b. Myxomycetes of the nature reserve near Wałbrzych (SW Poland). Part II. Dependence on the substrate and seasonality. Acta Mycol. 39 (2): 147-159.

\section{Obserwacje śluzowców na drewnie i ściółce bukowej}

\section{Streszczenie}

Artykuł prezentuje dane dotyczące występowania śluzowców w wybranych rezerwatach w Polsce Środkowej, w których buk zwyczajny osiąga północno-wschodnią granicę zasięgu. Przedstawiono listę 30 gatunków śluzowców, które występowały na substracie bukowym, zarówno drewnie jak i ściółce. W pracy przyjęto trójstopniową skalę rozkładu drewna. Wyróżniono: 1 - fazę inicjalną, 2 - optymalną i 3 - finalną kłód, pni i pniaków zalegających w dnie lasu. Na tak określonym substracie przedstawiono gatunki śluzowców. Wśród nich, sześć to taksony nowe dla tego terenu: Fuligo leviderma, Hemitrichia clavata, Collaria arcyrionema (Lamproderma arcyrionema), Physarum leucophaeum, P. notabile, Stemonitis pallida (Seta, Drozdowicz 2004). 